\title{
Polygala retiefiana (Polygalaceae), a new species described from South Africa
}

\author{
JORGE PAIVA $^{1}$, ESTRELA FIGUEIREDO $^{1,2} \&$ GIDEON F. SMITH $^{1,3,4}$ \\ ${ }^{1}$ Centre for Functional Ecology, Departamento de Ciências da Vida, Universidade de Coimbra, 3001-455 \\ Coimbra, Portugal. \\ ${ }^{2}$ Department of Botany, P.O. Box 77000, Nelson Mandela Metropolitan University, Port Elizabeth, 6031 \\ South Africa.estrelafigueiredo@hotmail.com (corresponding author) \\ ${ }^{3}$ Office of the Chief Director: Biosystematics Research \& Biodiversity Collections, South African National \\ Biodiversity Institute, Private Bag X101, Pretoria, 0001 South Africa. \\ ${ }^{4}$ H.G.W.J. Schweickerdt Herbarium, Department of Plant Science, University of Pretoria, Pretoria, 0002 \\ South Africa.
}

\begin{abstract}
A new species of Polygala (Polygalaceae), P. retiefiana, is described from the KwaZuluNatal and Free State provinces of South Africa. It is endemic to the country.
\end{abstract}

Key words: plant taxonomy, biodiversity, Polygalaceae, Polygala retiefiana, endemic, South Africa

With the order Polygalales no longer accepted, the Polygalaceae belong now to the order Fabales, the circumscription of which (Chase et al. 1993) includes four families: Fabaceae, Polygalaceae, Quillajaceae and Saurianaceae. These families have as common characteristic the monosymmetric flowers (Tucker 2003) where one of the petals, or two united petals, form a keel (carina) which covers the androecium and gynoecium. This group of plants with papilionaceous or pseudo-papilionaceous flowers is well-characterised both molecularly (APG III 2009) and ontogenically (Bello et al. 2010). Interfamilial relationships and patterns of floral evolution were also found between these four families (Bello et al. 2012). 
The Polygalaceae include c. 1300 species in 17-25 genera, depending on the classification followed, as several genera have been recently segregated (Pastore et al. 2010, Abbott, 2011, Pastore 2012, Pastore \& Abbott 2012). They have a cosmopolitan distribution but are absent from the Arctic and Antarctic regions. Polygala Linnaeus (1753: 701) is a cosmopolitan genus with about 750 species, widespread mainly in tropical and subtropical regions. The genus is divided into several subgenera, but with the exception of three species from northwestern Africa, all African species belong to the subgenus Polygala. In Africa, Polygala is represented by over 210 species (Paiva 1998) of which c. 80 species occur in southern Africa (Botswana, Lesotho, Namibia, South Africa and Swaziland). Of these, c. 55 species are endemic to the region.

At first sight the flowers of plants of Polygala resemble papilionaceous (legume) flowers. However, the similarity is only superficial: in the flowers of species of Polygala the wings are comprised of two petaloid sepals, not petals; instead of the standard of the papilionaceous flower, the polygalaceous flower has two petals; and whereas the papilionaceous flower has a keel composed of two petals, Polygala flowers have a single, boat-shaped, central, inferior petal, called a carina, with a fimbriate appendage (crest). This peculiar flower morphology has attracted considerable attention to the genus. The first reference to African Polygala known in the literature is by Commelin (1697: tab. 46) who illustrated Polygala arborea myrtifolia [=Polygala myrtifolia Linnaeus (1753: 703)], a South African species introduced and naturalized in many mild-climate regions of the world (Paiva 1998). In spite of interest in the genus, and its high level of endemism in the southern African region, Polygala was only partially revised for South Africa by Levyns (1955), for Namibia by Friedrich-Holzhammer \& Merxmüller (1968) and for Botswana by Exell (1960), but a complete revision is still lacking. As part of on-going revisionary work on the genus in Africa (Paiva 1998, 2007, 2008, 2011), an undescribed species of Polygala was recently recorded in the collections of South Africa's National Herbarium (PRE). The species is here described and illustrated. 


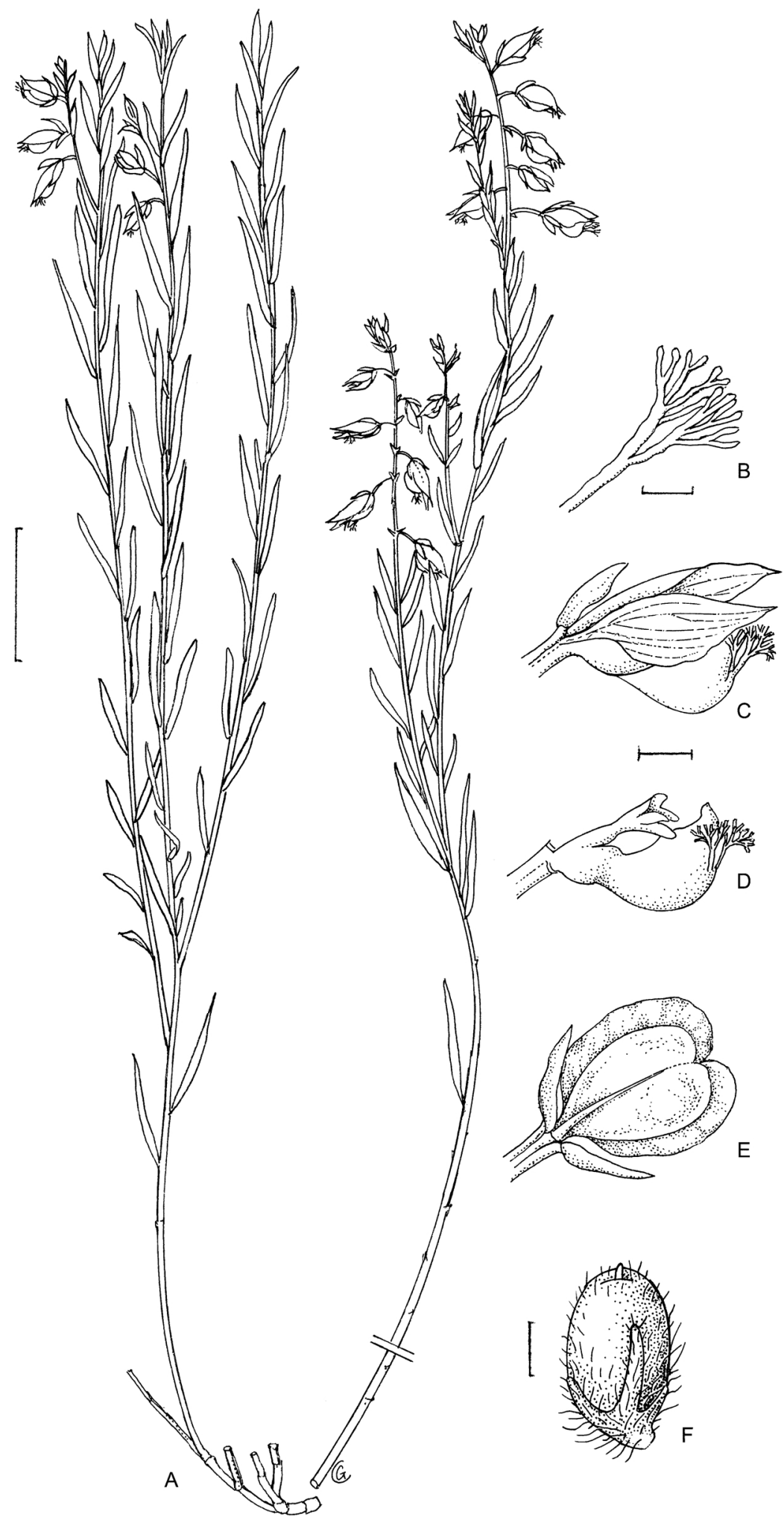

Figure 1: A. Habit. B. Crest. C. Flower. D. Flower with calyx removed. E. Fruit. F. Seed. A-D from Jacobsz 347; E from Trauseld 471; F from Jacobsz 137.Scale bars: A, $20 \mathrm{~mm}$; B, $0.5 \mathrm{~mm}$; C-E, $2 \mathrm{~mm}$ (between C\&D); F, 1 mm. Artist: Gillian Condy. 


\section{Taxonomy}

Polygala retiefiana Paiva \& Figueiredo, sp. nov. (Fig. 1)

Diagnosis: - It is distinct from the closely related Polygala garcinii based on its smaller flowers that have asymmetric wing sepals of 8.0-8.5 $\mathrm{mm}$ long (instead of symmetric wing sepals, 8-11 mm long) and a carina of 4.0-4.5 mm long (instead of 7-10 mm long).

Type:-SOUTH AFRICA: Free State: Harrismith District, Berg Manyenyeza op die plaas [on the farm] Rensburgskop, 2829AD, 1800 m elev., 17 January1977, Jacobsz 347 (holotype: PRE!).

Perennial herb, with a woody base. Stems slender, 20-30 cm long, branched, angled, glabrous. Leaves alternate, subsessile (petiole up to $0.5 \mathrm{~mm}$ long, glabrous), linear, 8-18 $\times 0.5-1.0 \mathrm{~mm}$, acute, glabrous. Flowers pinkish, in few-flowered (5-16 flowers), terminal racemes, erect, up to $8 \mathrm{~cm}$ long, rachis and peduncle glabrous; pedicels $3-4 \mathrm{~mm}$ long, glabrous; bract linear, 2.0-2.5 mm long, glabrous, persistent; bracteoles linear, ca. $1 \mathrm{~mm}$ long, glabrous, persistent. Posterior sepal linear-lanceolate, $4.00 \times 1.25 \mathrm{~mm}$, acute, glabrous; wing sepals asymmetrically elliptic, $8.0-8.5 \times 5 \mathrm{~mm}$, glabrous; anterior sepals linear-lanceolate, $3 \times 1 \mathrm{~mm}$, acute, glabrous, free. Upper petals obovate, 3.0-3.5 $\times$ $1.5 \mathrm{~mm}$, unequally bifid; carina 4.0-4.5 × 1.75-2.0 mm; crest 1.5-2.0 mm long, fimbriate. Stamens 8. Capsule widely-elliptic to almost obovate in outline, $5.0-5.5 \times 4$ $\mathrm{mm}$, asymmetrically bilobate, glabrous, winged (wing $0.5-0.75 \mathrm{~mm}$ wide). Seeds ellipsoid, 2.75-3.0 × $1.25 \mathrm{~mm}$, sparsely sericeous-pubescent; caruncle $0.5 \mathrm{~mm}$ long, long-hairy, with three long appendages, ca.1.5 mm long.

Distribution and habitat:-_Polygala retiefiana is endemic to South Africa, where it occurs in grasslands in summer-rainfall areas, at elevations of up to $1800 \mathrm{~m}$ above sea level, around the border of the KwaZulu-Natal and Free State provinces of the country and neighbouring Lesotho (Fig. 2). All the collections of this species recorded to date 


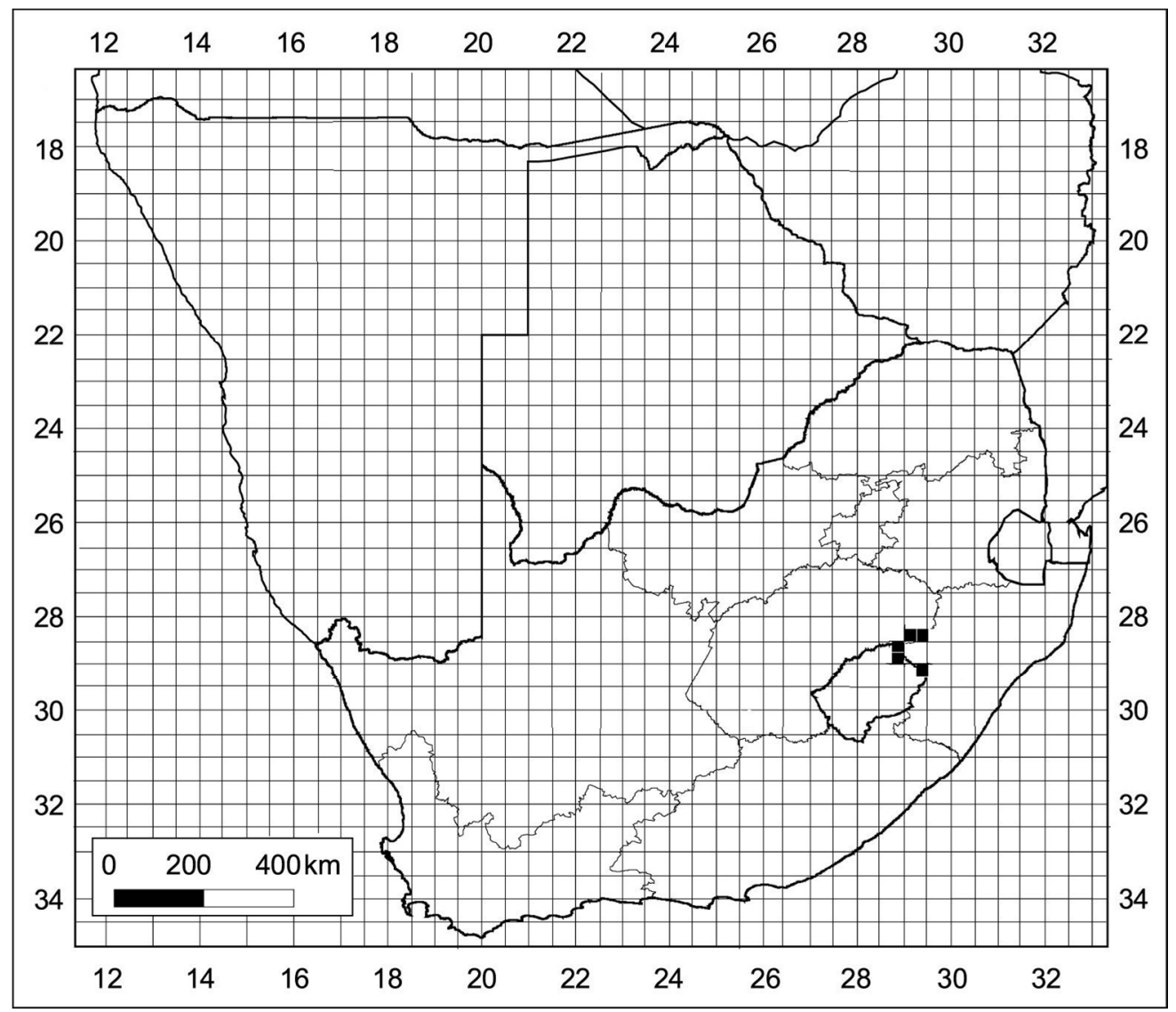

Figure 2: Distribution of Polygala retiefiana.

have been made on the Drakensberg proper, close to and immediately north of the Drakensberg Alpine Centre of Endemism (DAC) as defined by Van Wyk \& Smith (2001).

Phenology:-Flowers recorded from October to March, therefore from early to late summer in the Southern Hemisphere.

Conservation status:-This species is represented in PRE by five collections only, the most recent one dating from 1977, which may be an indication of its rarity.

Etymology:-The species is named after Dr Elizabeth Retief (born in Bloemfontein on 11 October 1947) a South African taxonomist who worked at the National Herbarium of 
South Africa from 1970 to 2010. She co-authored the recently described Polygala sekhukhuniensis Retief, S.J.Siebert \& A.E.van Wyk in Siebert et al. (2010).

Additional specimens examined (paratypes):- SOUTH AFRICA: Free State: Harrismith District, 2829AC, 4 March 1962, Jacobsz 137 (PRE!). KwaZulu-Natal: Bergville district, Drakensberg National Park, slopes of Plowman's Kop, 2828DB, 29 October 1938, Hafstrom \& Acocks 822 (PRE!); Mont-aux-Sources, 2828DD, $1800 \mathrm{~m}$ elev., 4 October 1950, Sidey 2018 (PRE!); Eastcourt district, Giant's Castle Game Reserve, Mumden Stream, 2929AB, 1620 m elev., date unrecorded, Trauseld 471 (PRE!).

\section{Discussion}

Polygala retiefiana belongs to Polygala sect. Psychanthus (Rafinesque (1814: 116)) De Candolle (1824: 321). The species included in this section are distributed in southern and southeastern Africa. The main characters distinguishing the section are: flowers in terminal or pseudo-lateral racemes, anterior sepals free, wing sepals large and covering the capsule, upper petals bilobed to subentire and seeds pubescent and carunculate, with the three branches of the caruncle \pm the same length.

The specimens of Polygala retiefiana had been previously identified as P. refracta, but the two species are easily distinguishable on account of the terminal racemes of $P$. retiefiana (as opposed to lateral racemes of $P$. refracta), in other words, the secondary fertile branches (with racemes) in P.refracta are much shorter compared to P.retiefiana. Polygala retiefiana appears to be more closely related to Polygala garcinii, a species also endemic to South Africa, but which is restricted to the winter-rainfall areas of the Western Cape province. Polygala retiefiana differs from $P$. garcinii in the smaller size of the flowers and shape of the wing sepals. A characteristic feature of the new species is that the caruncle is longhairy, with three long appendages.

Polygala retiefiana occurs in summer-rainfall areas of South Africa, but it appears to be sparsely distributed, as no recent specimens were found in PRE; the most recent specimen found in the collection dates from 1977. Since the area where the species occurs is well 
represented in PRE, the lack of recent material of this species may be an indication of its relative rarity.

\section{Acknowledgements}

Dr Elizabeth (Liesbet) Retief is thanked for drawing our attention to this new species. Ms Gillian Condy of the South African National Biodiversity Institute is thanked for illustrating the species. The Curator of the National Herbarium of South Africa (PRE), Mr Erich van Wyk, is thanked for allowing access to the collections. An anonymous referee is thanks for comments.

\section{References}

Abbott, J. R. (2011). Notes on the disintegration of Polygala (Polygalaceae) with four new genera for the flora of North America. Journal of the Botanical Research Institute of Texas 5: $125-137$.

APG III (Angiosperm Phylogeny Group) (2009) An update of the Angiosperm Phylogeny Group classification for the orders and families plants: APG III. Botanical Journal of the Linnean Society 161: 105-121.

Bello, M.A, Hawkins, J.A. \& Rudall, P.J. (2010) Floral ontogeny in Polygalaceae and its bearing on the homologies of keeled flowers in Fabales. International Journal of Plant Sciences 171 (5): 482-498.

Bello, M.A, Rudall, P.J. \& Hawkins, J.A. (2012) Combined phylogenetic analyses reveal interfamilial relationships and patterns of floral evolution in eudicot order Fabales.

Cladistics 28: 393-421.

Chase, M.W., Soltis, D.E., Olmstead, R.G., Morgan, D., Les, D.H., Mishler, B.D., Duvall, M.R., Price, R.A., Hills, H.G., Qiu, Y.-L., Kron, K.A., Rettig, J.H., Conti, E., Palmer, J.D., 
Manhart, J.R., Sytsma, K.J., Michaels, H.J., Kress, W.J., Karol, K.G., Clark, W.D., Hedrén, M., Gaut, B.S., Jansen, R.K., Kim, K.-J., Wimpee, C.F., Smith, J.F., Furnier, G.R., Strauss, S.H., Xiang, Q.-Y., Plunkett, G.M., Soltis, P.S., Swensen, S.M., Williams, S.E., Gadek, P.A., Quinn, C.J., Eguiarte, L.E., Golenberg, E., Learn, G.H., Jr., Graham, S.W., Barrett, S.C.H., Dayanandan, S. \& Albert, V.A. (1993) Phylogenetics of seed plants: an analysis of nucleotide sequences from the plastic gene rbcL. Annals of the Missouri Botanical Garden 80: 528-580.

Commelin, J. (1697) Horti Medici Amstelodamensis rariorum tam Orientalis, quam Occidentalis Indiae, aliarumque peregrinarum plantarum 1. P. \& J. Blaeu, Amsterdam, $220 \mathrm{pp}$.

De Candolle, A.P. (1824) Prodromus systematis naturalis regni vegetabilis 1 . Treuttel et Würtz, Paris, 745 pp.

Exell, A.W. (1960). Polygalaceae. In: Exell, A.W. \& Wild, H. (eds.) Flora Zambesiaca, 1, Part 1. Crown Agents for Oversea Governments and Administrations, 336 pp.

Friedrich-Holzhammer, M. \& Merxmüller, H. (1968) 73. Polygalaceae. In: Merxmüller, H., Prodromus einer Flora von Südwestafrika 2. Cramer, Lehre, 7 pp.

Levyns, M.R. (1955) The species of Polygala in the South-Western Cape Province. South African Journal of Science 21: 9-50.

Linnaeus, C. (1753) Species Plantarum 2. L. Salvius, Stockholm, 639 pp.

Paiva, J. (1998) Polygalarum africanarum et madagascariensium prodromus atque gerontogaei generis Heterosamara Kuntze, a genere Polygala L. segregati et a nobis denuo recepti, synopsis monographica. Fontqueria 50: 1-346. 
Paiva, J. (2007) Polygalaceae. In: Beentje, H. J. \& Ghazanfar, S. A. (eds.) Flora of Tropical East Africa. Royal Botanic Gardens, Kew, 64 pp.

Paiva, J. (2008) Polygalaceae. In: Figueiredo, E. \& Smith, G. F., Plants of Angola.

Strelitzia 22: 132-134.

Paiva, J. (2011) Polygalaceae. In: Sosef, M.S., Florence, J., Banak, R. \& Bourobou, H.P. (eds.) Flore du Gabon 42. Margraf Pulishers, Weikersheim; Backhuys Publishers, Leiden.

Pastore, J.F.B. (2012) Caamembeca: generic status and new name for Polygala subgenus Ligustrina (Polygalaceae). Kew Bulletin 67(3): 435-442.

Pastore, J.F.B., Cardoso, D.B.O.S., Aymard C., G.A. (2010) A synopsis, new combinations, and synonyms in Acanthocladus (Polygalaceae). Novon 20(3): 317-324.

Pastore, J.F.B. \& Abbott, J.R. (2012) Taxonomic notes and new combinations for Asemeia (Polygalaceae). Kew Bulletin 67 (4): 801-813.

Rafinesque, C.S. (1814) Ordine eltrologici o definizioni degli ordini della primae classe delle piante. Specchio delle scienze 1: 113-148.

Siebert, S.J., Retief, E., van Wyk, A.E. \& Struwig, M. (2010) A new species of Polygala (Polygalaceae) from ultramafic soils in Sekhukhuneland, South Africa, with notes on its ecology. South African Journal of Botany 76(2): 345-353.

Tucker, S.C. (2003) Floral development in legumes. Plant Physiology 131: 911-926.

Van Wyk, A.E. \& Smith, G.F. (2001). Regions of floristic endemism in southern Africa. A review with emphasis on succulents. Umdaus Press, Hatfield, 199 pp. 